\title{
Mekanisme Pembatasan Penanaman Modal Asing Dalam Bidang Perkebunan Menurut Hukum Positif Di Indonesia
}

\section{Mechanism of Limiting Foreign Investment in Plantations According To Positive Law In Indonesia}

\author{
Annna Stephanie*, Kartina Pakpahan, Yolanda Natalia Isabel \& Gandace Siregar
}

Prodi Studi Ilmu Hukum, Fakultas Hukum, Universitas Prima Indonesia, Indonesia

Diterima: 21 Agustus 2020; Direview: 22 Agustus 2020; Disetujui:29 Agustus 2020

*Coresponding Email: annasirait97@gmail.com Email: kartinapakpahan@unprimdn.ac.id

\begin{abstract}
Abstrak
Penanaman modal asing di Indonesia dalam bidang perkebunan memberikan dampak yang positif bagi pembangunan nasional. Perlunya dorongan dan dukungan dalam usaha perkebunan dengan menciptakan kebijakan-kebijakan yang salah satunya mampu meningkatkan penanaman modal asing dalam usaha bidang perkebunan. Tujuan penelitian ini guna untuk menganalisa dari segi hukum yang berlaku di Indonesia dan untuk mengetahui faktor-faktor yang menjadi penghambat pembatasan penanaman modal asing di bidang perkebunan. Penelitian ini menggunakan metode yuridis normatif, yaitu dengan cara melakukan pendekatan kualitatif. Kesimpulan dari penelitian ini adalah mekanisme pembatasan penanaman modal asing di bidang perkebunan diatur dalam Undang-Undang Nomor 25 Tahun 2007 Tentang Penanaman Modal Asing dan Undang-Undang Nomor 39 Tahun 2014 Tentang Perkebunan yang dimana peraturan tersebut wajib diperhatikan oleh penanaman modal asing dalam melakukan investasi dalam bidang perkebunan di Indonesia. Adanya faktor yang menjadi penghambat penanaman modal asing adalah terbiasanya pelaku usaha melakukan penyuapan kepada pejabat Negara, adanya permasalahan terbatasnya membuka suatu badan usaha karena proses pembebasan lahan yang terlampau lama.
\end{abstract}

Kata Kunci: Pembatasan Penanaman Modal Asing, Penanaman Modal Asing, Perkebunan.

\begin{abstract}
Foreign investment in Indonesia in the plantation sector has a positive impact on national development. The need for encouragement and support in the plantation business by creating policies, which one is able to increase foreign investment in the plantation business. The purpose of this research is to analyze from the perspective of the prevailing law in Indonesia and to find out the factors that hinder the restriction of foreign investment in the plantation sector. This study uses a normative juridical method, namely by using a qualitative approach. The conclusion of this study is that the mechanism for limiting foreign investment in the plantation sector is regulated in Law Number 25 of 2007 concerning Foreign Investment and Law Number 39 of 2014 concerning Plantations, where these regulations must be considered by foreign investment in investing in plantation sector in Indonesia. The factors that hinder foreign investment are the usual business actors bribing State officials, the problem of being limited to opening a business entity because the land acquisition process is too long.
\end{abstract}

Keywords: Restrictions on Foreign Investment, Foreign Investment, Plantation.

How to Cite: Stephanie, A, Pakpahan, K.,, Isabel, Y.N., \& Siregar. G., (2020). Mekanisme Pembatasan Penanaman Modal Asing Dalam Bidang Perkebunan Menurut Hukum Positif Di Indonesia. Journal of Education, Humaniora and Social Sciences (JEHSS). 3 (2): 342-349. 


\section{PENDAHULUAN}

Salah satu indikator Penanaman Modal Asing (PMA) yakni pembangunan ekonomi yang memiliki peran dalam membangun kekuatan ekonomi Indonesia menjadi lebih kuat (Ratnasari F.A, 2017). Dengan adanya penanaman modal asing yang masuk ke dalam Indonesia, maka dapat menambah pendapatan serta adanya peluang lapangan pekerjaan bagi masyarakat (Masheri, 2015). Perkebunan memiliki potensi dalam meningkatkan perkembangan perekonomian nasional di Indonesia (Rizky Pratama, 2018). Usaha perkebunan wajib didukung dengan beberapa kebijakan dalam membangun PMA dalam bentuk bidang usaha perkebunan di Indonesia. Tujuan penanaman modal asing untuk mendapatkan keuntungan antara para pihak (Chandrawulan A.A, 2011).

Pada tahun 2019 penanaman modal asing di Indonesia mengalami peningkatan dari 3 tahun sebelumnya, hal ini terlihat dalam data Badan Koordinasi Penanaman Modal (BKPM) pada sektor tanaman pangan, perkebunan dan peternakan, bahwa jika di kumulatifkan mulai dari periode Januari hingga Desember 2019, jumlah nilai investasi asing sebanyak 5.242.546 US\$ Juta dengan jumlah proyek sebanyak 1318 proyek, sedangkan 3 tahun sebelumnya, jumlah nilai investasi asing terbanyak ada di tahun 2018 dengan nilai investasi asing sebanyak 1.721.235,9 US\$ Ribu dengan kumulatif periode Januari hingga Desember dengan jumlah proyek 660 proyek. Di sini terlihat bahwa jumlah nilai penanaman modal asing kian meningkat, yang dengan kata lain sangat dapat membantu peningkatan nilai devisa negara. Dengan adanya UU (UndangUndang) No. 25 Tahun 2007 tentang Penanaman Modal, pemerintah memberikan perlindungan hukum terhadap investor baik secara langsung ataupun tidak langsung serta memberikan kemudahan-kemudahan kepada penanam modal asing, sehingga pelaksanaan penanaman modal asing di Indonesia memberikan dampak yang positif bagi pembangunan nasional.

Pemerintah bertugas membuat kebijakan untuk memperlancar proses penanaman modal (Ageng D.P, 2015). Bentuk pengaturan dan pengawasan dari pemerintah terhadap pelaksanaan modal asing di Indonesia adalah dengan dikeluarkannya kebijakan mengenai dibatasinya investasi (penanaman modal) terhadap penanam modal asing serta penanam modal dalam negeri secara adil (Kadir, 2018; Abdina, 2019; Winda et al, 2020; Hartono et al., 2020). Adanya peraturan yang spesifik dan tidak bersifat rangkap dengan maksud meninjau dan mengelola penanaman modal tersebut. Peraturan ini bertujuan untuk mengembangkan penanaman modal asing dalam bidang perkebunan di Indonesia serta mengembangkan hukum yang berlaku. Sehingga dapat menarik perhatian para investor serta membuat para investor merasa aman dalam berinvestasi di Indonesia (Nainggolan, 2007).

\section{METODE PENELITIAN}

Pada penelitian ini, penulis menggunakan metode yuridis normatif. Adapun sifat penelitian yang digunakan adalah deskriptif analitis. Penelitian yang bersifat deskriptif analitis berfungsi untuk mendeskripsikan gambaran terhadap objek yang diteliti (Sugiyono, 2009). Menggunakan pendekatan kualitatif. Pendekatan kualitatif adalah merupakan tata cara penelitian yang menghasilkan data deskriptif, yaitu secara tertulis atau lisan, dan perilaku nyata (Setiono, 2002), guna untuk menganalisa suatu keadaan maupun suatu objek dalam konteksnya, serta mendapatkan pemahaman yang mendasar mengenai permasalahan yang dihadapi dengan menggunakan data kualitatif berupa gambar, kata, maupun kejadian. Metode penelitian hukum normatif meneliti hukum dari perspektif internal dengan menggunakan norma hukum sebagai objek penelitiannya. Penelitian hukum normatif berdasarkan bahan baku utama yaitu mempelajari hal yang bersifat teoritis (peraturan) dengan menggunakan data sekunder yaitu aturan hukum (peraturan perundang - undangan, buku - buku, dokumen berhubungan erat dengan penelitian) (Soerjono, 2001). 
Annna Stephanie, Kartina Pakpahan, Yolanda Natalia Isabel \& Gandace Siregar, Mekanisme Pembatasan Penanaman Modal Asing Dalam Bidang Perkebunan Menurut Hukum Positif Di Indonesia

\section{HASIL DAN PEMBAHASAN \\ Peraturan Hukum Positif Yang Terkait Dengan Mekanisme Pembatasan Penanaman Modal Asing Dalam Bidang Perkebunan Di Indonesia.}

Berdasarkan Pasal 5 ayat (2) Undang-Undang (UU) Nomor 25 Tahun 2007 Tentang Penanaman Modal, kegiatan penanaman modal asing wajib dalam bentuk perseroan terbatas dan berkedudukan di Indonesia (Tobing, 2014). Peraturan hukum positif yang berkenaan dengan mekanisme pembatasan penanaman modal asing dalam bidang perkebunan di Indonesia terdiri dari:

Tabel 1. Mekanisme Pembatasan Penanaman Modal Dalam Bidang Perkebunan Menurut Hukum Positif Di Indonesia Yang Diatur Dalam Peraturan Menteri.

\begin{tabular}{|c|c|}
\hline No. & Peraturan Menteri. \\
\hline 1. & $\begin{array}{l}\text { Peraturan Menteri Keuangan Nomor 181/PMK.05/2008 Tahun } 2008 \text { Tentang Pelaksanaan } \\
\text { Investasi Pemerintah. }\end{array}$ \\
\hline 2. & $\begin{array}{l}\text { Peraturan Menteri Perindustrian Nomor 106/M-IND/PER/10/2012 Tahun } 2012 \text { Tentang Daftar } \\
\text { Mesin, Barang Dan Bahan Produksi Dalam Negeri Untuk Pembangunan Atau Pengembangan } \\
\text { Industri Dalam Rangka Penanaman Modal. }\end{array}$ \\
\hline 3. & $\begin{array}{l}\text { Peraturan Menteri Negara Agraria/Kepala Badan Pertanahan Nasional Nomor } 2 \text { Tahun } 1999 \\
\text { Tentang Tata Cara Pemberian Izin Lokasi Penanaman Modal Asing/Penanaman Modal Dalam } \\
\text { Negeri. }\end{array}$ \\
\hline 4. & 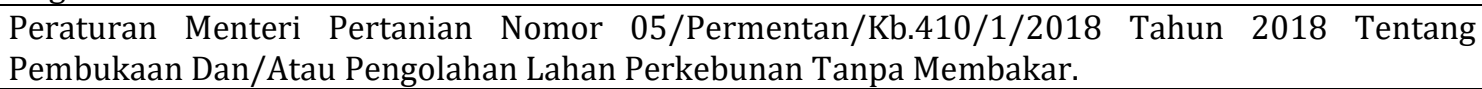 \\
\hline 5. & $\begin{array}{l}\text { Peraturan Menteri Pertanian Nomor 21/Permentan/Kb.410/6/2017 Tahun } 2017 \text { Tentang } \\
\text { Pedoman Perizinan Usaha Perkebunan. }\end{array}$ \\
\hline 6. & $\begin{array}{l}\text { Peraturan Menteri Pertanian Nomor 08/Permentan/Kb.400/2/2016 Tahun } 2016 \text { Tentang } \\
\text { Pedoman Perencanaan Perkebunan Berbasis Spasial. }\end{array}$ \\
\hline 7. & $\begin{array}{l}\text { Peraturan Menteri Pekerjaan Umum Nomor 13/Prt/M/2012 Tahun } 2012 \text { Tentang Pedoman } \\
\text { Pengelolaan Aset Irigasi. }\end{array}$ \\
\hline 8. & $\begin{array}{lllll}\text { Peraturan Menteri Pertanian Nomor } & \text { 36/Permentan/Ot.140/7/2009 } & \text { Tahun } 2009 \text { Tentang } \\
\text { Persyaratan Penilai Usaha Perkebunan. } & & & & \\
\end{array}$ \\
\hline 9. & $\begin{array}{lllll}\text { Peraturan Menteri Pertanian Nomor } & \text { 07/Permentan/Ot.140/2/2009 } & \text { Tahun } 2009 \text { Tentang } \\
\text { Pedoman Penilaian Usaha Perkebunan. } & & & \\
\end{array}$ \\
\hline 10. & $\begin{array}{llllll}\begin{array}{l}\text { Peraturan Menteri Pertanian Nomor 33/Permentan/Ot.140/7/2006 Tahun } 2006 \\
\text { Pengembangan Perkebunan. }\end{array} & & & & \\
\end{array}$ \\
\hline
\end{tabular}

Tabel 2. Mekanisme Pembatasan Penanaman Modal Dalam Bidang Perkebunan Menurut Hukum Positif Di Indonesia Yang Diatur Dalam Keputusan Menteri.

\begin{tabular}{llll}
\hline No. & Keputusan Menteri. & \\
\hline 1. & Keputusan Menteri Pertanian Nomor 353 Tahun 2003 Tentang Tata Cara Pelaksanaan \\
Pengembangan Perkebunan Dengan Pola Pir-Trans.
\end{tabular}

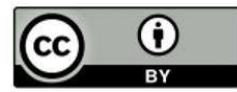


Tabel 3. Mekanisme Pembatasan Penanaman Modal Dalam Bidang Perkebunan Menurut Hukum Positif Di Indonesia Yang Diatur Dalam Peraturan Pemerintah.

\begin{tabular}{ll}
\hline No. & Peraturan Pemerintah. \\
\hline 1. & $\begin{array}{l}\text { Peraturan Pemerintah Nomor 24 Tahun } 2018 \text { Tentang Pelayanan Perizinan Berusaha Terintegrasi } \\
\text { Secara Elektronik. }\end{array}$ \\
\hline 2. & Peraturan Pemerintah Nomor 24 Tahun 2015 Tentang Penghimpun Dana Perkebunan. \\
\hline 3. & Peraturan Pemerintah Nomor 29 Tahun 2016 tentang Perubahan Modal Dasar Perseroan Terbatas. \\
\hline 4. & $\begin{array}{l}\text { Peraturan Pemerintah Nomor 31 Tahun } 2009 \text { Tentang Perlindungan Wilayah Geografis Penghasil } \\
\text { Produk Perkebunan Spesifik Lokasi. }\end{array}$ \\
\hline 5. & $\begin{array}{l}\text { Peraturan Pemerintah Nomor 15 Tahun } 1999 \text { Tentang Bentuk-Bentuk Tagihan Tertentu yang } \\
\text { Dapat Dikompensasikan sebagai Setoran Modal. }\end{array}$ \\
\hline 6. & Peraturan Pemerintah Nomor 27 Tahun 1998 Tentang Penggabungan, Peleburan, Dan \\
Pengambilalihan Perseroan Terbatas.
\end{tabular}

Tabel 4. Mekanisme Pembatasan Penanaman Modal Dalam Bidang Perkebunan Menurut Hukum Positif Di Indonesia Yang Diatur Dalam Keputusan Kepala Badan.

\begin{tabular}{lllll}
\hline No. & Keputusan Kepala Badan. \\
\hline 1. & $\begin{array}{l}\text { Keputusan Kepala Badan Koordinasi Penanaman Modal Nomor 14 Tahun 2015 Tentang Pedoman } \\
\text { Dan Tata Cara Izin Prinsip Penanaman Modal. }\end{array}$ \\
\hline 2. & $\begin{array}{l}\text { Keputusan Kepala Badan Koordinasi Penanaman Modal Nomor } 71 \text { Tahun 2004 Tentang } \\
\text { Pengendalian Pelaksanaan Penanaman Modal. }\end{array}$ \\
\hline 3. & $\begin{array}{l}\text { Keputusan Kepala Badan Koordinasi Penanaman Modal Nomor } 66 \text { Tahun 2004 Tentang Pedoman } \\
\text { Dan Tata Cara Izin Prinsip Penanaman Modal. }\end{array}$ \\
\hline
\end{tabular}

Tabel 5. Mekanisme Pembatasan Penanaman Modal Dalam Bidang Perkebunan Menurut Hukum Positif Di Indonesia Yang Diatur Dalam Peraturan Presiden.

\begin{tabular}{ll}
\hline No. & Peraturan Presiden. \\
\hline 1. & $\begin{array}{l}\text { Peraturan Presiden Nomor 44 Tahun } 2016 \text { Tentang Daftar Bidang Usaha yang Tertutup dan Bidang } \\
\text { Usaha yang Terbuka. }\end{array}$ \\
\hline 2. & Peraturan Presiden Nomor 39 Tahun 2014 Tentang Daftar Negatif Investasi. \\
\hline 3. & Peraturan Presiden Nomor 16 Tahun 2012 Tentang Rencana Umum Penanaman Modal. \\
\hline 4. & $\begin{array}{l}\text { Peraturan Presiden Nomor } 27 \text { Tahun } 2009 \text { Tentang Pelayanan Terpadu Satu Pintu Di Bidang } \\
\text { Penanaman Modal. }\end{array}$ \\
\hline 5. & Peraturan Presiden Nomor 91 Tahun 2017 TentangPercepatan Pelaksanaan Berusaha. \\
\hline 6. & $\begin{array}{l}\text { Peraturan Presiden Nomor } 36 \text { Tahun 2010 Tentang Daftar Bidang Usaha yang Tertutup dan Bidang } \\
\text { Usaha yang Terbuka dengan Persyaratan di Bidang Penanaman Modal. }\end{array}$ \\
\hline
\end{tabular}

Tabel 6. Mekanisme Pembatasan Penanaman Modal Dalam Bidang Perkebunan Menurut Hukum Positif Di Indonesia Yang Diatur Dalam Undang-Undang.

\begin{tabular}{ll}
\hline No. & Undang-Undang. \\
\hline 1. & Undang-Undang No. 25 Tahun 2007 Tentang Penanaman Modal Asing. \\
\hline 2. & Undang-Undang No. 44 Tahun 2014 Tentang Badan Koordinasi Penanaman Modal. \\
\hline 3. & Undang-Undang Nomor 5 Tahun 1960 Tentang Peraturan Dasar Pokok-pokok Agraria. \\
\hline 4. & Undang-Undang Nomor 40 Tahun 2007 Tentang Perseroan Terbatas. \\
\hline 5. & Undang-Undang Nomor 13 Tahun 2003 Tentang Ketenagakerjaan. \\
\hline 6. & $\begin{array}{l}\text { Undang-Undang Nomor } 5 \text { Tahun } 1999 \text { Tentang Larangan Praktik Monopoli dan Persaingan Tidak } \\
\text { Sehat. }\end{array}$ \\
\hline 7. & Undang-Undang No. 39 Tahun 2014 Tentang Perkebunan. \\
\hline
\end{tabular}

\section{Mekanisme Pembatasan Penanaman Modal Dalam Bidang Perkebunan Menurut Hukum Positif Di Indonesia.}

Adapun peraturan yang wajib diperhatikan oleh penanam modal asing yang akan melakukan investasi dalam pendirian PMA di Indonesia yakni (Wicaksono, 2014) : 
1. Penanam modal dalam negeri maupun asing memiliki bidang usaha yang tertutup dan yang terbuka. Untuk bidang usaha yang terbuka bagi penanam modal asing harus mentaati beberapa pembatasan sesuai dengan peraturan yang berlaku.

2. Peraturan Kepala Badan Pusat Statistik Nomor 57 Tahun 2009 Tentang Klasifikasi Baku Lapangan Usaha sebagai peraturan yang wajib ditaati oleh penanam modal asing ketika mendirikan bidang usahanya untuk memastikan apakah sesuai dengan peraturan yang berlaku.

3. Peraturan Badan Koordinasi Penanaman Modal Nomor 12 Tahun 2013 Tentang Pedoman dan Tata Cara Perizinan dan Nonperizinan Penanaman Modal sebagai peraturan yang mengatur tentang perizinan maupun non perizinan penanaman modal asing di Indonesia.

4. Undang-Undang (UU) Nomor 40 Tahun 2007 Tentang Perseroan Terbatas sebagai peraturan yang mengatur persyaratan pendirian PT. Penanaman Modal Asing (PMA).

Beberapa hal yang diperlukan penanam modal asing untuk mendirikan suatu badan usaha di Indonesia (Wicaksono, 2014):

1. Mendapatkan izin prinsip dari berdasarkan Peraturan Badan Koordinasi Penanaman Modal (BKPM);

2. Mendapatkan akta pendirian PT. Penanaman Modal Asing (PMA) harus dari notaris;

3. Mendapatkan tempat tinggal dari pemerintah daerah setempat;

4. Mendapatkan NPWP dan keterangan Pengusaha Kena Pajak (PKP) dari kantor pajak;

5. Badan usaha diwajibkan mendapatkan izin usaha dari Badan Koordinasi Penanaman Modal (BKPM) dan dari Badan Pengkajian Dan Penerapan Teknologi (BPPT) untuk pelayanan perizinan terpadu.

6. Setiap badan usaha wajib melapor ke departemen Kementrian Ketenagakerjaan serta memiliki laporan kesejahteraan.

\section{Faktor-faktor Yang Menjadi Penghambat Pembatasan Penanaman Modal Asing Dalam Bidang Perkebunan}

Pemerintah Indonesia melakukan pengaturan dan pengawasan pelaksanaan penanaman modal asing, guna untuk mengontrol masuknya penanam modal asing yang tidak terbatas. Salah satunya dengan melakukan pembatasan penanaman modal asing. Latar belakang adanya pembatasan pada bidang usaha yang bisa dimasuki oleh penanam modal asing adalah pertama, industri yang dimasuki tidaklah harus bermodal besar dan tidak terlalu beresiko, oleh karna itu diatur oleh penanam modal dalam negeri. Kedua, industri tersebut lebih baik apabila dikerjakan oleh penanam modal dalam negeri dan ketiga, adanya kekhawatiran Negara apabila menerima perusahaan asing multinasional masuk ke Indonesia ditakutkan adanya pengambil alihan perusahaan domestik Indonesia. Adanya ketidakpastian hukum yang berpotensi menyebabkan terjadinya sengketa antara penanam modal asing dengan pemerintah terkait pembatasan yang diberlakukan di Indonesia (Mujibussalim, 2014). Oleh sebab itu, pemerintah membentuk suatu pengaturan yang menggolongkan bidang usaha mana yang terbuka dan tertutup untuk penanaman modal asing.

Terkait pembatasan penanaman modal asing dalam bidang perkebunan, terdapat beberapa faktor yang menjadi penghambat penanaman modal asing seperti:

1. Faktor yang pertama adalah para pelaku usaha Indonesia yang terbiasa melakukan penyuapan kepada pejabat negara (Firdaus, 2014), hal tersebut membuat para investor asing harus membayar sejumlah uang kepada pejabat negara agar proses perizinan bisa berjalan dengan lancar, tetapi kalau tidak membayar, maka proses perizinan bisa terlampau lama (Firdaus, 2014).

2. Faktor yang kedua adalah permasalahan terbatasnya pembebasan lahan untuk membuka suatu badan usaha karena proses pembebasan lahan terlampau lama. Dalam prosesnya, bisa membutuhkan 5-10 tahun. Hal itulah yang memperlama para investor asing untuk mengerjakan suatu kegiatan investasinya (Rizky, 2019). 
3. Faktor yang ketiga adalah tarif pajak yang terbilang cukup tinggi sebesar $25 \%$ daripada beberapa negara pesaing, meskipun pemerintah sudah merencanakan pengurangan jumlah tarif pajak menjadi 20\% mulai tahun 2021 (Republika, 2019).

4. Faktor yang ke empat adalah dalam sejarah perekonomian di Indonesia, seperti yang diilustrasikan oleh Daftar Negatif Investasi, yang membatasi kepemilikan asing dalam bidang-bidang tertentu (Republika, 2019).

Pihak investor asing yang akan menanamkan modal dalam bidang usaha perkebunan wajib bekerjasama dengan pihak Indonesia melalui perseroan terbatas. Hal tersebut diatur dalam Pasal 39 ayat (3) Undang-Undang (UU) Nomor 39 Tahun 2014 Tentang Perkebunan. Jenis usaha perkebunan dapat mencakup usaha budi daya tanaman perkebunan, usaha pengolahan hasil perkebunan, dan usaha jasa perkebunan sebagaimana hal ini diatur dalam Pasal 41 ayat (1) Undang-Undang (UU) Nomor 39 Tahun 2014. Dan semua kegiatan tersebut hanya dapat dilakukan jika mendapatkan izin usaha perkebunan dari pihak berwenang yang terdapat dalam Undang-Undang (UU) Nomor 39 Tahun 2014.

Para investor asing yang sudah memperoleh perizinan dari pemerintah untuk mendirikan suatu badan usaha dalam bidang perkebunan (Dedi P.I, 2019), maka memiliki jangka waktu kontrak kerjasama dengan Indonesia sesuai dengan jangka waktu berlakunya kerjasama yang tidak boleh melebihi dari 30 tahun Undang-Undang (UU) Nomor 1 Tahun 1967.

Adanya larangan yang tidak dapat dilakukan oleh para investor asing pada saat akan mendirikan suatu badan usaha yaitu, tidak diperbolehkan masing-masing pelaku usaha perkebunan membuka maupun mengolah lahan dengan cara membakar serta masing-masing pelaku usaha wajib memiliki sistem sarana dan prasarana pengendalian lahan dan kebun serta ketentuan lebih lanjut diatur dalam Peraturan Menteri. Hal tersebut diatur dalam Pasal 56 Undang-Undang (UU) Nomor 39 Tahun 2014.

Adanya larangan tersebut menyebabkan munculnya sengketa oleh investor asing di bidang perkebunan. Timbulnya sengketa dikarenakan tidak tercapai persetujuan antar dua belah pihak maupun lebih. Oleh karena itu, pemerintah memberikan kompensasi ganti rugi yang disetujui oleh kedua belah pihak (Suardhana, 2019).

Dalam mencegah terjadinya sengketa dalam pembatasan penanaman modal asing dibidang perkebunan yang tidak mengikuti peraturan yang berlaku di Indonesia, maka antara pemerintah dengan investor asing melakukan penyelesaian sengketa melalui arbitrase internasional dan disepakati oleh masing-masing pihak. Apabila para investor asing menyelesaikan sengketa melalui sarana arbitrase internasional, mereka akan lebih terlindungi (Evi Deliana, 2019).

Jika para investor asing melakukan suatu pelanggaran akan dikenakan sanksi administratif berupa denda, pemberhentian sementara dari usaha perkebunan serta pencabutan izin usaha perkebunan yang diatur dalam Pasal 64 ayat (2) Undang-Undang Nomor 39 Tahun 2014. Bagi badan usaha yang tidak memiliki izin akan dikenakan sanki pidana yang diatur dalam Pasal 47 ayat (1) Undang-Undang Nomor 39 Tahun 2014.

Serta adanya sanksi perdata dalam penyelesaian sengketa yang terjadi maka dilakukan penyelesaian melalui pengadilan atau di luar pengadilan, mengenai besarnya tuntutan kerugian maupun kerusakan yang dilakukan akibat perbuatan yang melanggar hukum seperti pencemaran lingkungan. Dalam Pasal 34 ayat (1) dan pasal 35 ayat (1) Undang-Undang (UU) Perlindungan dan Pengelolaan Lingkungan Hidup serta pasal 1365 KUHPer (Kitab Undang-Undang Hukum Perdata) mengenai ketentuan perbuatan melawan hukum, bentuk denda kepada pihak berwajib adalah wujud denda yang diberikan kepada pemerintah sebagai ganti rugi senantiasa wajib dibayarkan kepada pemerintah sebagai pengawas lingkungan (Sriwaty, 2007).

\section{SIMPULAN}

Penanaman modal asing dalam bidang perkebunan di Indonesia wajib berbentuk Perseroan Terbatas dan berkedudukan di Indonesia. Hukum positif yang berkenaan dengan mekanisme pembatasan penanaman modal asing dalam bidang perkebunan di Indonesia terdiri 
dari: Peraturan Menteri, Keputusan Menteri, Peraturan Pemerintah, Keputusan Kepala Badan, Peraturan Presiden, dan Undang-Undang.

Mekanisme pembatasan penanaman modal asing dalam bidang perkebunan menurut hukum positif di Indonesia yakni harus berdasarkan oleh beberapa aturan yang wajib diperhatikan oleh penanam modal asing yang akan melakukan investasi dalam pendirian PMA di Indonesia. Beberapa peraturan tersebut adalah mengenai daftar bidang usaha yang tertutup dan yang terbuka, lapangan usaha dalam mendirikan bidang usahanya untuk memastikan apakah sesuai dengan peraturan yang berlaku, pedoman dan tata cara perizinan dan nonperizinan penanaman modal, dan perseroan terbatas sebagai peraturan yang mengatur persyaratan pendirian pt. penanaman modal asing (PMA).

Faktor yang menjadi penghambat penanaman modal asing yang pertama adalah para pelaku usaha Indonesia yang terbiasa melakukan penyuapan kepada pejabat negara, hal tersebut membuat para investor asing harus membayar sejumlah uang kepada pejabat negara agar proses perizinan bisa berjalan dengan lancar, tetapi kalau tidak membayar, maka proses perizinan bisa terlampau lama, yang kedua adalah permasalahan terbatasnya pembebasan lahan untuk membuka suatu badan usaha karena proses pembebasan lahan terlampau lama. Dalam prosesnya, bisa membutuhkan 5-10 tahun. Hal itulah yang memperlama para investor asing untuk mengerjakan suatu kegiatan investasinya, yang ketiga adalah tarif pajak yang terbilang cukup tinggi sebesar 25\% daripada beberapa negara pesaing, meskipun pemerintah sudah merencanakan pengurangan jumlah tarif pajak menjadi 20\% mulai tahun 2021, dan yang ketiga adalah adanya Daftar Negatif Investasi (DNI), yang membatasi kepemilikan asing dalam bidangbidang tertentu.

\section{DAFTAR PUSTAKA}

Abdina, M.F. (2019). Analisis Dampak Perkebunan Kelapa Sawit Terhadap Sosial dan Ekonomi Masyarakat di Kabupaten Asahan. Journal of Education, Humaniora and Social Sciences (JEHSS). 2 (2): 292304.

Abidin, R.F, (2017), Harmonisasi Peraturan Penanaman Modal Asing Dalam Bidang Pertambangan Mineral Dan Baturbara Berdasarkan Prinsip Keadila. Az Zarqa'. Vol.9. No.2. Diakses dari http://ejournal.uinsuka.ac.id/syariah/azzarqa/article/view/1468

BKPM, "Daftar Negatif Investasi di Indonesia", https://www.investindonesia.go.id/id/artikelinvestasi/detail/daftar-negatif-investasi-di-indonesia, diakses pada 24 April 2020.

BKPM, "Tentang BKPM", https://www.bkpm.go.id/id/tentang-bkpm/profil-lembaga, diakses pada 24 April 2020.

Chandrawulan. (2011), Hukum Perusahaan Multinasional, Liberalisasi Hukum Perdagangan Internasional dan Hukum Penanaman Modal, Bandung: Alumni

Deliana E, (2019), Pengaturan Penyelesaian Sengketa Penanaman Modal Dalam Peraturan Daerah Nomor 7 Tahun 2018 Tentang Penanaman Modal Provinsi Riau. Sasi. Vol.26 No.1. diakses dari https://fhukum.unpatti.ac.id/jurnal/sasi/article/view/208/pdf

Firdaus, M.A. (2014), Perlindungan Hukum Terhadap Penanaman Modal Pada Bidang Usaha Perkebunan Di Indonesia, Skripsi, Fakultas Hukum Universitas Islam Negeri Syarif Hidayatullah, Jakarta.

Hukum Online, "Mengapa Penanaman Modal Asing Harus Dalam Bentuk PT?", https://www.hukumonline.com/klinik/detail/ulasan/lt50759704ac972/penanamanmodal/,diakses pada 22 April 2020.

Insar, D.P., (2019), Perlindungan Hukum Terhadap Penanaman Modal Pada Bidang Usaha Perkebunan Di Indonesia, Skripsi, Fakultas Hukum Universitas HKBP Nomensen, Medan.

Kadir, A. (2018). Analisis Penetapan Nilai Jual Obyek Pajak Bumi dan Bangunan Sektor Perkebunan sebagai Upaya Peningkatan Sumber Pendapatan Daerah. Journal of Education, Humaniora and Social Sciences (JEHSS). 1 (1): 9-15.

Masheri, (2015), Pengaruh Kebijakan Perkebunan Terhadap Penanaman Modal (PMDN Dan PMA). Jom Fisip. Vol.2 No.1. Diakses dari https://www.neliti.com/publications/31995/pengaruh-kebijakanperkebunan-terhadap-penanaman-modal-pmdn-dan-pma-studi-kasus

Maulandy Rizky B. K, "Pemerintah Diminta Segera Atasi Masalah yang Hambat Investasi",https://www.liputan6.com/bisnis/read/4034645/pemerintah-diminta-segera-atasimasalah-yang-hambat-investasi, diakses pada 24 April 2020.

348 http://mahesainstitute.web.id/ojs2/index.php/jehss @ mahesainstitut@gmail.com

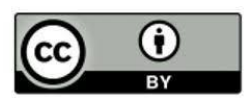


Mujibassalim, dkk, (2014), Hambatan Hukum Dalam Penanaman Modal Asing Agribisnis Kehutanan Di Provinsi Aceh. Kanun Jurnal Ilmu Hukum, Vol.64.

Nainggolan, M, (2010), Kendala-Kendala Penanaman Modal Di Bidang Perkebunan Kelapa Sawit Di Provinsi Riau Di Tinjau Dari Undang-Undang Nomor 18 Tahun 2004 Tentang Perkebunan, Skripsi, Fakultas Hukum Universitas Islam Indonesia, Yogyakarta.

Pratama, R, (2018), Perlindungan Hukum Terhadap Penanaman Modal Dalam Sektor Usaha Perkebunan Kelapa Sawit Di Indonesia, Skripsi, Fakultas Hukum Universitas Jember, Jember.

Prayitno, A.D, (2015), Tinjauan Yuridis Tentang Perubahan Daftar Bidang Usaha Yang Tertutup Dan Daftar Bidang Usaha Yang Terbuka Dengan Persyaratan Di Bidang Penanaman Modal Menurut Peraturan Presiden Republik Indonesia Nomor 39 Tahun 2014, Skripsi, Fakultas Hukum Universitas Jember, Jember.

Republika, "Ini Faktor Penghambat Investasi Asing di Indonesia", https://www.google.com/amp/s/m.republika.co.id/amp/q0sl6u370, artikel diakses pada 26 April 2020.

Rudi Hartono, Marlina \& Muaz Zul. Pelaksanaan Peraturan Menteri BUMN Nomor: PER01/MBU/2011 Tentang Penerapan Tata Kelola Yang Baik (Good Corporate Governance) Pada BUMN (Studi Kasus

Di PT Perkebunan Nusantara IV). ARBITER: Jurnal Ilmiah Magister Hukum. 2(1) 2020: 23-32.

Setiono, (2002), Pemahaman Terhadap Metode Penelitian Hukum, Program Studi Ilmu Hukum Pascasarjana UNS, Surakarta.

Soekanto, S., \& Mamudji, S., (2011), Penelitian Hukum Normatif (Suatu Tinjauan Singkat), Jakarta: Rajawali Pers.

Sriwaty, (2007), Penerapan Sanksi Perdata Terhadap Korporasi Dalam Sengketa Lingkungan Hidup, Skripsi, Fakultas Hukum Universitas Sumatera Utara, Medan.

Suardhana, C.V. (2019), Perlindungan Hukum Terhadap Penanaman Modal Asing pada Sektor Perkebunan di Indonesia. $\quad$ Prasada. Vol.4 No.1. Diakses dari https://ejournal.warmadewa.ac.id/index.php/prasada

Sugiyono, (2009), Metode Penelitian Kualitatif Dan R\&D, Bandung: Alfabeta.

ThareqAkmalHibatullah,

“Apaitudaftarnegatifinvestasi (DNI)?",https://smartlegal.id/smarticle/layanan/2018/12/21/apa-itu-daftar-negatif-investasidni/, diakses pada 21 Februari 2020.

Wikipedia, “Pelayanan Terpadu Satu Pintu” https://id.wikipedia.org/wiki/Pelayanan_Terpadu_Satu_Pintu, diakses pada 24 April 2020.

Winda, W., Tedja, K., \& Pakpahan, K. (2020). Tindak Pidana Mengiklankan Hasil Usaha Perkebunan Yang Menyesatkan Konsumen. Journal of Education, Humaniora and Social Sciences (JEHSS), 3(1), 17-25. doi:https://doi.org/10.34007/iehss.v3i1.167

Peraturan Perundang-undangan:

Peraturan Presiden Nomor 44 Tahun 2016 Tentang Daftar Bidang Usaha yang Tertutup dan Bidang Usaha yang Terbuka.

Peraturan Presiden Nomor 39 Tahun 2014 Tentang Daftar Negatif Investasi.

Undang-UndangNomor 5 Tahun 1960 TentangPeraturanDasarPokok-pokokAgraria.

Undang-Undang Nomor 25 Tahun 2007 Tenang Penanaman Modal.

Undang-Undang Nomor 39 Tahun 2014 Tentang Perkebunan.

Undang-Undang Nomor 1 Tahun 1967 Tentang Penanaman Modal Asing.

Undang-Undang Nomor 40 Tahun 2007 Tentang Perseroan Terbatas. 